\title{
THE EFFECT OF OUTDOOR LEARNING ON TEACHING WRITING OF DESCRIPTIVE TEXT OF TENTH YEAR GRADE STUDENTS' OF SMA SWASTA TAMANSISWA BINJAI AT ACADEMIC YEAR 2017/2018
}

\author{
Conny, Shelly Miranti \\ STKIP Budidaya Binjai
}

\begin{abstract}
This study aimed to find out whether using Outdoor Learning significantly affects on teaching writing of descriptive text of tenth year grade students' of SMA SWASTA TAMANSISWA Binjai at Academic Year 2017/2018 . In this study, Outdoor Learning as the independent variable (X) and students' descriptive text as the dependent variable (Y), with the hypothesis: using Outdoor Learning significantly affects on teaching writing of descriptive text of tenth year grade students' of SMA SWASTA TAMANSISWA Binjai at Academic Year 2017/2018. The population of this study was the tenth year grade students' of SMA SWASTA TAMANSISWA Binjai, which consisted of 161 sudents. The sample was taken by using random sampling, the total sample was 60 students. Then, the sample was divided into two groups, the group taught by using outdoor learning was as the experimental group and the group taught without outdoor learning was as the control group. The writer used test as the instrument of collecting data. The data was analyzed by using t-test formula. Based on the data analysis, it was found that the value of $t$-observed $\left(\mathrm{t}_{\mathrm{o}}\right)$ was higher than the value of $\mathrm{t}$-table, $\left(\mathrm{t}_{\text {observed }}=4,13>\mathrm{t}_{\text {table }}=1,67\right)$. Therefore, the hypothesis proposed by the writer was accepted. In the other words, using Outdoor Learning significantly affects on teaching writing of descriptive text of tenth year grade students' of SMA SWASTA TAMANSISWA Binjai at academic year 2017/2018.
\end{abstract}

\section{Keywords : Outdoor Learning, Teaching Writing, Descriptive Text.}

\section{CHAPTER I}

\section{A.The Background of The Study}

Jack C. Richard and Willy A. Renandya states, "writing is the most difficult skill for second language learners to master. The difficulty lies not only in generating and organizing ideas, but also in translating these ideas into readable text. $^{1 \text { "، }}$

There are many problems in writing text like, grammar problem, the organization of the writing, the content of the text, and also vocabularies. In the tenth year of senior high school, the basic competency that should be achieved in

\footnotetext{
${ }^{1}$ Richards, Jack C, Renandya, Willy A.Eds, Methodology In Language Teaching Cambridge University Press p. 306
} 
the writing English subject is that the students have ability to develop and produce written simple functional text in the descriptive text.

Descriptive is describes a particular person, place, or thing. It is purposed is to tell about the subject by describing its features without including personal opinions. Descriptive text is one of the functional texts which is difficult enough to be learnt by the students. The quotation explains that descriptive text is closely relate to daily life. It means the students can write easily about it. Another problem is they do not give much attention and enthusiasm to write it. They are getting stuck to write into a text such as describing a place because they need to see the real situation of a place. They cannot imagine about the place without seeing the real place directly. When the teacher asks the students to tell about pictures, or something that they have seen, or based on their experiences, they can explain about it. On the other hand, when the teacher asks students to write text on a paper, they still get problems to write into a text. They may have some ideas in their mind, but they get stuck to express their ideas in writing. All of difficulties that are faced by students should be solved by the teacher, especially for English teacher, by right method. There are a lot of methods and techniques to get the English teaching effectively. However, due to those problems, it needs to be handled with right method which can make students get more interesting in writing. So, the writer decides using the Outdoor Learning Method. Why does the writer choose this method? because Outdoor Learning is suitable for descriptive text which needs more thoughts, minds and ideas. Outdoor learning method is defined as a learning approach that uses the atmosphere outside the classroom as a medium of transformation of concepts presented in lesson. So materials which have studied applied in a real and imagination and engage the entire sensing devices. 


\section{CHAPTER II}

\section{REVIEW OF LITERATURE}

\section{A. The Theoretical Framework}

\section{Writing}

Writing is one of a way of people to communicate to each other for expressing their thinking and feeling. Writing is unnatural act like speaking. writing needs more efforts than speaking does. Writing needs hard effort to dig and manage the ideas which are from the writer's mind and pours it into written from effectively so it will be readable. Before starting to write, the writer needs to remember and think first what the writer is going to write. The writer has to recall al memory related to the topic which is going to be written to get the details. Writing is one of the most significant cultural accomplishments of human being. It allows us to record and conveys information and stories beyond the immediate moment. ${ }^{2}$ Writing allows us to communicate at a distance, either at a distant place or at distant time. There are a lot of definitions stated by experts; Raymond states one of them, he defined that writing is more than a medium of communication. ${ }^{3}$ It means that writing is not just the way to communicate to each other but also as means of ideas and emotional expression.

Jacob defines writing is a process of putting thoughts and ideas into the words then combined into sentences in a form of paragraph in which every sentence in related one to another. ${ }^{4}$ Jacob says a good product of writing must convey five general aspects: content (relevance to the topic), organization (good logical order), vocabulary (the choice of word), language used (complete and grammatical) and mechanic (punctuation, capitalization, coherence). ${ }^{5}$ The kinds of tasks set for learners may not be motivating, relevant or indeed very

\footnotetext{
${ }^{2}$ Henry Rogers. Writing Systems: A Linguistic Approach. (Oxford: Blackwell Publishing: 2005), P:1

3 James C Raymond. Writing is Unnatural Act. (New York: The Murray Printing Company: 2003), P:2 7

${ }^{4}$ Jacob et.al., English Composition Program, Trach ESL Composition Program, (USA: University of Linois, 2001), P:34.

${ }^{5}$ Ibid., P: 33.
} 
communicative. Boardman states that writing is a continuous process of thinking and organizing, rethinking, and reorganizing.

Writing makes word permanent, and thus expands the collective memory of human beings from the relatively small store that we can remember and pass on orally to the infinite capacity of a modern library. ${ }^{6}$ Writing is also a way of finding out what people know and what people need to learn. Writing is a powerful tool to organize overwhelming events and make them manageable. Writing is really a form of thinking using the written word.

Based on the explanation above, it can be inferred that writing is a productive skill for writing an indirect communication and the nature of the character is very different from that expressed by speaking directly, therefore writing is included an ability toward writing to construct the meaning. To construct the meaning the writer should have skills and know which skills and strategies are appropriate for the type of the text, and understand how to apply them to accomplish the writing purpose.

\section{B. Related Studies}

There are some studies related in this study that was previously conducted by other researchers. The first researcher is Dwi Styanto Nugroho. The study is about "The Application of Outdoor Learning with A Medium Build Space to Increase Interest in Mathematics and Students Learning Outcomes of Eighth Grade Students of SMP Negeri 2 Geyer". The purpose of this study is to increase the interest and the learning of mathematics through the application of learning outside the classroom (Outdoor Learning). Based on this study, it can be concluded that the applied of Outdoor Learning method and the results showed that interest in mathematics and the learning outcomes of students has increased.

The second researchers are Anies Rahmayati. The study is about "The Application of Outdoor Learning Process by Using Puzzle Blocks to Increase Student Learning Activities and Conservation Attitudes". In this study, the demand of the curriculum is make students active in learning and teacher as

\footnotetext{
${ }^{6}$ James C Raymond. Writing is Unnatural Act ..., P:2.
} 
facilitator to design creative learning. The purpose of this research was to determine the increase in student learning activities, conservation and understanding of the concept. Based on this study, the results showed that the application of Outdoor Learning with puzzle blocks can enhance student's activities than indoor learning.

The third researchers are Dewi Aslika Wati. The study is about "The Implementation of Outdoor Learning by Utilizing Surroundings Environment to Improve Learning Achievement of Science Subject of 4th Grade in SD 1 Rahtawu Gebog Subdistrict Kudus Regency”. The purpose of this research are: (1) to improve learning achievement of science subject about material of physical environment changes, (2) to describe improving student activity, and (3) to describe improving teacher skill on learning management trough outdoor learning method by utilizing surroundings environment. Based on this study, it can be concluded that the result of using Outdoor Learning by utilizing surroundings environment showed that there is an improvement of classical learning completeness about material of physical environment changes that is significant enough.

Based on some researchers above, it doesn't find that there is no research which discusses the Outdoor Learning method about English subject. The research above discusses about Math subject and Science subject. It can be concluded that Outdoor Learning is not only used for specific subject such as teaching English for writing descriptive text, but also it can be used for others subject which needs more thinking when learning teaching process. However, there are so many advantages in implementing Outdoor Learning method, it allows the teacher to be more creative and keeps the students from being bored.

\section{The Conceptual Framework}

English is one of the essential subjects which is learnt from elementary school up to university level. Though the students have learnt English for some years, the result of their learning is unsatisfactory enough. They still get difficulty in mastering the four basic language skills. 
Writing is as one of the four skills that is still a serious problem at schools, especially senior high school. The students feel bored, get stuck in writing text, even they have no idea in writing a simple text.

Teacher needs to give more attention for this phenomenon and train the students by using a technique. Outdoor Learning can be used as an enjoyable method for the students and the students will be easier to express their ideas and imagination through this method by looking the object directly by studying outside.

The conceptual framework of this study is the effect of Outdoor Learning On Teaching Writing of Descriptive Text of Tenth Year Grade Students' of SMA SWASTA TAMANSISWA Binjai at Academic Year 2017/2018",

\section{The Hypothesis}

Based on the theoretical and framework above, the writer formulates two alternatives of the hypothesis of the study, as follows :

Ho : There isn't a significant effect of Outdoor Learning method on teaching writing of descriptive text.

Ha : There is a significant effect of Outdoor Learning method on teaching writing of descriptive text.

\section{CHAPTER III}

RESEARCH METHOD

\section{A.The Location and Time of the Study}

This study will be conducted at SMA Tamansiswa Binjai. It is a formal education institution located at Jl. Jend. Sudirman No.11 Binjai, Kec. Binjai Kota. There were three reasons why the writer chose this school as a research location:

1. First, the writer wants to know the ability of students in writing ability.

2. Second, this school is accessible in term of efficiency in fund and time.

3. Third, based on information that the writer had received from the teacher, in this school was never held research about "The Effect of Outdoor Learning On Teaching Writing of Descriptive Text".

This study will be conducted on October-November 2017. It's the period in the first semester of new academic year. 


\section{B. The Design of the Study}

This research is an experiment or quantitative that means there is a certain experiment applied to the sample. In conducting this study, the writer applied experimental research design which needs two groups being experimented, one is control group and the other is experimental group.

Table 3.2

The Design of the Study

\begin{tabular}{|c|c|c|c|}
\hline $\mathrm{X}_{1}$ & $\mathrm{~T}_{1}$ & $\mathrm{Y}_{1}$ & $\mathrm{~T}_{2}$ \\
\hline $\mathrm{X}_{2}$ & $\mathrm{~T}_{1}$ & $\mathrm{Y}_{2}$ & $\mathrm{~T}_{2}$ \\
\hline
\end{tabular}

Legends:

$\mathrm{X}_{1} \quad$ : Experimental group is taught by using outdoor learning method

$\mathrm{X}_{2} \quad$ : Control group is taught without outdoor learning method

$\mathrm{T}_{1} \quad$ : Pre - Test

$\mathrm{T}_{2} \quad$ : Post - Test

$\mathrm{Y}_{1} \quad$ : Treatment by outdoor learning method

$\mathrm{Y}_{2} \quad$ : Treatment without using outdoor learning method

\section{The Population and Sample}

\section{C.1 Population}

The population consists of five parallel classes with the total number of 161 students. This population can be seen clearly in table 3.2 that presents the total number of students from each class.

Table 3.3

\begin{tabular}{|c|c|c|}
\hline No & Class & Total Number \\
\hline 1 & X-IPA 1 & 30 \\
\hline 2 & X- IPA 2 & 30 \\
\hline 3 & X-IPA 3 & 30 \\
\hline 4 & X-IPS-1 & 30 \\
\hline 5 & X-IPS-2 & 41 \\
\hline $\begin{array}{l}\text { Total number of } \\
\text { population }\end{array}$ \\
\hline
\end{tabular}




\section{C.2 Sample}

The first small roll of paper which is taken by the researcher in the box is X - IPA 1 as experiment group which use treatment (using Outdoor Learning method) and the second small roll of paper that taken by the researcher in the box is X - IPS 1 as control group which not use any methods. The number of students both in experimental class and control class are 30 students, so the total number of sample is 60 students.

Table 3.4

The Sample of The Study

\begin{tabular}{|c|c|c|c|}
\hline No & Class & $\begin{array}{c}\text { Number of } \\
\text { students }\end{array}$ & Status \\
\hline 1 & X-IPA 1 & 30 & $\begin{array}{c}\text { Experiment } \\
\text { Class }\end{array}$ \\
\hline 2 & X-IPS 1 & 30 & Control Class \\
\hline
\end{tabular}

\section{The Variable of the Study}

Variable can be classified into two types namely: Independent Variable (X) and Dependent Variable (Y).

Independent Variable (X) is the factor which is measured, manipulated, or selected by experimenter to determine is relationship to observe phenomenon. Dependent Variable (Y) is the factor which is observed and measured to determine the effect of the independent variable. ${ }^{7}$

In this study, there were two variables that are examined: outdoor learning as the independent variable and students' descriptive text teaching as dependent variable .

\section{E. The Instrument of The Study}

The instrument used for collecting the data is a test. The form of the test is writing a text. Pre-test and Post-Test will be given to the students. Pre-test is administrated to measure the previous ability or the basic knowledge of students writing ability. The test will be given before treatment of teaching both groups.

${ }^{7}$ Bruce Truckman, Conducting Educational Research, (New York: Harcourt Brace Jovanovich Publisher, 2003), P:59. 
The post-test will be given to measure the students' achievement after teaching learning process. Contents+Organization+Vocabulary+Language use+ Mechanics $=$ Total score

$$
30+20+20+25+5=100100 / 1=100
$$

In scoring the data of this study, the score for content is 30 points, organization is 20 points, vocabulary is 20 points, language use is 25 points and mechanics is 5 points. So, for all components, the maximum score is 100 .

\section{F. The Technique of the Data Analysis}

1.The formula of calculating the mean:

$$
M E A N: \sum \frac{f x}{N}
$$

Where:

$\begin{array}{ll}\mathrm{M} & =\text { mean } \\ \Sigma f x & =\text { total of the test } \\ \Sigma \mathrm{N} & =\text { total of the students }\end{array}$

2.The formula of calculating the standard deviation:

$$
\begin{aligned}
& S x=\sqrt{\frac{n \sum x^{2}-\left(\sum x\right)^{2}}{n(n-1)}} \\
& S y=\sqrt{\frac{n \sum y^{2}-(y)^{2}}{n(n-1)}}
\end{aligned}
$$

Where:

$$
\begin{array}{ll}
\text { Sx } & \text { : Standard Deviation (x) } \\
x^{2} & : \text { Average (x) } \\
\text { Sy } & : \text { Standard Deviation (y) } \\
y^{2} & : \text { Average (y) } \\
n & : \text { the amount of data }
\end{array}
$$

3. Hypothesis Testing 
To see whether significant effect of outdoor learning in hypothesis on teaching writing of descriptive text the result of the test is calculated by using the t-test formula:

$$
t=\frac{M x-M y}{\sqrt{\left(\frac{s x^{2}+s y^{2}}{N x+N y-2}\right)\left(\frac{1}{N x}+\frac{1}{N y}\right)}}
$$

Where:

Mx : Mean of experimental group

My : Mean of control group

$\mathrm{Nx} \quad$ : Numbers of students in experimental group

Ny : Numbers of students in control group

Dx : standard deviation of experimental group

Dy : standard deviation of control group

Ho: $\rho=0$ : There is no a significant effect of using outdoor learning method on teaching writing of descriptive text

Ha: $\rho=0$ : There is a significant effect of using outdoor learning method on teaching writing of descriptive text

Degree of freedom $=n-2$ and $x=0,05$, accept Ho if $t_{\text {observed }} \leq t_{\text {table }}$ or reject Ho if $t_{\text {observed }} \geq t_{\text {table. }}$

From the data on appendix vi, it can be known that:
Mx: 13
My: 8,
$\mathrm{Sx}_{1}^{2:} 580$
$s Y_{1}^{2}: 393,5$
$n \boldsymbol{X}: 30$
$n Y: 30$

The t-calculation can be calculated based on the data above, it can be known that:

$$
\mathrm{t}=\frac{M x-M y}{\sqrt{\left(\frac{s x^{2}+s y^{2}}{N x+N y-2}\right)\left(\frac{1}{N x}+\frac{1}{N y}\right)}}
$$




$$
\begin{aligned}
& \mathrm{t}=\frac{13-8,5}{\sqrt{\left(\frac{580+393,5}{30+30-2}\right)\left(\frac{1}{30}+\frac{1}{30}\right)}} \\
& \mathrm{t}=\frac{8,87}{\sqrt{\left(\frac{973,5}{58}\right)\left(\frac{2}{60}\right)}} \\
& \mathrm{t}=\frac{4,5}{\sqrt{(16,79)(0,07)}} \\
& \mathrm{t}=\frac{4,5}{\sqrt{1,18}} \\
& \mathrm{t}=4,13
\end{aligned}
$$

\section{CHAPTER IV}

\section{THE DATA AND RESEARCH FINDING}

\section{A. Research Finding Description}

\section{Pre test Finding}

The pre-test was held in the first meeting before the students taught without treatment. The students were asked to write descriptive text in the instrument. The result of pre-test can be seen on appendix 5. It can be seen from the table of pretest result that the average score is 66,3 in experimental class and in control class is 67 .

\section{Post test Finding}

The post-test was held in the last meeting after the students taught about text by using Outdoor Learning method. The students were asked to write descriptive text in the instrument. The result of post-test that can be seen on appendix 6. It can be seen from the table of post-test result that the average score is 79,3 in experimental class and in control class is 75,6 . 


\section{B. Data Analysis}

Table 4.1

The Result of Pre Test and Post Test and Deviation of Experiment Class

\begin{tabular}{|c|c|c|c|c|c|}
\hline Code & $\begin{array}{c}\text { Pre } \\
\text { Test }\end{array}$ & $\begin{array}{c}\text { Post } \\
\text { Test }\end{array}$ & $\begin{array}{c}\boldsymbol{s} \boldsymbol{X} \\
(\text { Post- } \\
\text { Pre) }\end{array}$ & $\boldsymbol{s} \boldsymbol{X}_{\boldsymbol{I}}$ & $\boldsymbol{s} \boldsymbol{X} 1^{2}$ \\
\cline { 1 - 4 } $\boldsymbol{\Sigma}$ & 1990 & 2380 & 390 & \multirow{2}{*}{0} & 580 \\
\hline $\boldsymbol{M}$ & 66,3 & 79,3 & 13 & & \\
\hline
\end{tabular}

Table 4.2

The Result of Pre Test and Post Test and Deviation of Control Class

\begin{tabular}{|c|c|c|c|c|c|}
\hline Code & $\begin{array}{l}\text { Pre } \\
\text { Test }\end{array}$ & $\begin{array}{l}\text { Post } \\
\text { Test }\end{array}$ & $\begin{array}{c}Y \\
\text { (Post } \\
\text {-Pre) }\end{array}$ & $\begin{array}{r}s Y \\
1\end{array}$ & $s Y 1^{2}$ \\
\hline$\Sigma$ & $\begin{array}{c}201 \\
3\end{array}$ & 2268 & 255 & \multirow{2}{*}{0} & \multirow{2}{*}{$\begin{array}{c}393 \\
5\end{array}$} \\
\hline$M$ & 67 & $\begin{array}{c}75, \\
6\end{array}$ & 8,5 & & \\
\hline
\end{tabular}

C. Hypothesis Testing

The formula if t-test and distribution table of the $\mathrm{t}$-critical value was applied in testing the hypothesis. The basis of testing hypothesis is as follows: The calculation of the scores by using t-test for the degree of freedom (df): $58\left(n_{1}+n_{2}\right.$ -2 or $30+30-2)$ at the level significance $a=0,05(5 \%)$ that $t$-obeserved is 4,13 and the t-table is 1,67 . Therefore, the hypothesis is accepted. In the other words, using outdoor learning method significanly affects on teaching writing of descriptive text of tenth year students of SMA SWASTA TAMANSISWA Binjai at academic year 2017/2018.

\section{CHAPTER V}

\section{CONCLUSION AND SUGGESTIONS}

\section{A. Conclusion}

From the result of the data analysis in the previous chapter, the writer came to the conclusion that in testing the hypothesis, the value of t-observed $\left(t_{0}\right)$ is higher than the value of t-table, $\left(t_{o}=4,13>t_{t}=1,67\right)$. Therefore, the hypothesis 
proposed by the writer is accepted. In the other words, using outdoor learning method significanly affects on teaching writing of descriptive text of tenth year students of SMA SWASTA TAMANSISWA Binjai at academic year 2017/2018.

\section{B. Suggestions}

Considering seen the result of the analysis and also the conclusions above, the writer would like to share the following suggestions:

1. In teaching writing, the teachers should be creative and inovative, teaching writing by using outdoor learning method is effective, learning outside is refresh students' mind.

2. In learning writing text some teaching aids should be provided to make the students more interested in the materials taught.

3. Descriptive text writing will be more exciting for the students if the teachers use the right method, especially outdoor learning method because it can increase the students' thinking by seeing the object directly.

4. Considering to take data from school, the other researchers should prepare and manage everything for doing the study at school well.

5. Finally, the result of the study can make the contribution for developing a better educational world in future.

\section{REFERENCES}

Adelia Vera, Outdoor Learning Method. Jogjakarta: Diva Press, 2012.

ArtonoWardiman, et. al. English in Focus, 2000.

Barbara Fine clouse, The student write, McGraw-Hill Companies, Inc, 2004.

Betty Mattix Dietsch, Reasoning \& Writing Well, Ohio: McGraw Hill, 2003.

Database right Oxford University press. Oxford Learner's Pocket Dictionary New York :Oxford University Press, 2008.

Donald Pharr and Santi Buscemi, Writing Today, 2004.

Donn Byrne, Teaching Writing Skill, England: Longman, 2002.

George E. Wishon and Julia M. Burks,Let's Write English, New York: Litton Educational Piblishing, 1980. 
Henry Rogers. Writing Systems: A Linguistic Approach. Oxford: Blackwell Publishing, 2005.

Hughes. A, Testing For Language Teachers Second Edition, Cambridge University Press, 2003.

Jack C. Richards and Willy A. Renandya, Methodology in Language Teaching (An Anthology of Current Practice), Cambridge: Cambridge University Press, 2002.

Jacob et.al., English Composition Program, Trach ESL Composition Program, USA: University of Linois, 2001.

James C Raymond. Writing is Unnatural Act, 1990.

James C Raymond. Writing is Unnatural Act. New York: The Murray Printing Company: 2003

Jerry G. Gebhard, Teaching English as a Foreign or second Language, 2001.

Jessy Hammond, et.al., English for Social Purposes, Sydney: Macquaire University, 2000.

John Langan, English Skill: Eight Edition, 2003.

John S Hedgcock, Dana R Ferris.Teaching Reader Of English. New York : Routledge, 2009

Lund, The Definition of Outdoor Learning, 1989.

Mark Anderson, Text type in English 3, (Australia: Macmillan Education Australia Pty Ltd, 1998.

Mark Anderson and Kathy Anderson, Text Type in English 3, Australia: MacMillan, 1998.

Mark Anderson and Katty Anderson, Text Type in English 2, Australia: MacMillan, 1998

Michael E. Adelstein and Jean G. Pival, The Writing Commitment, HARCOURT, BRACE JOVANOVICH, INC 1976.

NU hidayati, 2010. Improving Students' Ability In Writing Procedure Text Using Realia. Hhtp://googleweblight.com. accessed of february 2,2015

Regina L. Smalley and Mary K. Ruetten, Refining Composition Skill, New York, 
2004.

Ria Sirait, translated Beyond Teaching and Learning Jogjakarta: Nuansa, 2003

Richards, Jack C, Renandya, Willy A.Eds, Methodology In Language Teaching Cambridge University Press, 2000.

Santi V. Buscemi, A Reader for Developing Writers, (New York: McGraw-Hill, 2006.

Sudjana and Rivai, Learning Media Bandung, Sinar Baru Algesundo, 2010. 